\title{
El Niño: Dispositivos de criação em tempos de pandemia
}

\author{
William Axel da Silva Moreira \\ Instituto Federal do Ceará - IFCE, Brasil \\ E-mail:waxel.moreira@gmail.com \\ Fernando Lira Ximenes \\ Instituto Federal do Ceará - IFCE, Brasil \\ E-mail: fernandoliraximenes@gmail.com
}

\section{Resumo}

Abstract

Esta pesquisa, inspirada na cartografia como abordagem metodológica, traça o mapa do processo de criação do vídeo performance solo "El niño". O estudo apresenta, como extração da experiência, possibilidades criativas contemporâneas. O artigo também apresenta a construção de um discurso acerca das criações contemporâneas em período de isolamento social, vivido por conta do novo coronavírus - COVID 19.
This research, inspired by cartography as a methodological approach, maps the process of creating the solo performance video El niño. The studio presents contemporary creative possibilities as an extraction from experience. The article also presents the construction of a discourse on contemporary creations in a period of social isolation, experienced by the pandemic of the new corona virus - COVID 19.

\section{Palavras-chave}

Dispositivos de Criação. Tecnologia. Vídeo Performance.
Keywords

Creation Devices. Technology. Video Performance. 


\section{Introdução}

Em 2020, a Organização Mundial da Saúde - OMS - declara que estamos vivendo uma pandemia do novo coronavírus - COVID 19. O isolamento social é uma medida que o mundo inteiro adota como forma de prevenir um colapso no sistema de saúde. O mundo vive essa pandemia que nos obriga a ficar distantes daquilo que é mais valioso no fazer teatral: o contato físico. De que maneira dar continuidade às nossas criações em um período no qual as pessoas precisam cumprir um isolamento social? Que metodologias de criação surgem nesse processo de isolamento?

Acontecimentos e notícias sobre o novo vírus que vem infectando as pessoas em todo o planeta vêm ocorrendo de maneira avassaladora. As pessoas isoladas em casa gritam a pedido de ajuda em todo o país. Não dá para fugir do assunto. $\mathrm{O}$ artista-criador quer falar sobre essa questão. Ele precisa, urgentemente, falar sobre isso e sobre a urgência para a criação dentro desse contexto.

Assim, este artigo é uma tentativa de organizar supostas metodologias de criação que surgem no período de isolamento social na criação do experimento "El niño" e como essa criação é percebida pelo artista-criador.

\section{- 2. A internet como uma Alegoria da Caverna}

No diálogo platônico "A República", o filósofo Platão apresenta sua teoria política, o que hoje é um legado para os estudos no campo das áreas de humanas. O Mito da Caverna ${ }^{1}$ está no livro VII de $A$ República e tem por objetivo estabelecer uma forma de governo perfeito por meio do conhecimento racional.

$\mathrm{Na}$ metáfora, Platão destaca elementos que são importantes para a macro compreensão do que a narrativa quer nos dizer. $\mathrm{O}$ primeiro elemento consiste em prisioneiros, que são pessoas comuns,

1 Mito da caverna é uma metáfora criada pelo filósofo grego Platão, que consiste na tentativa de explicar a condição de ignorância em que vivem os seres humanos e o que seria necessário para atingir o verdadeiro "mundo real", baseado na razão acima dos sentidos. uma espécie de população de massa; a caverna é um segundo elemento, que representa o próprio corpo, a zona de conforto; a saída da caverna representa um terceiro elemento, que é sair dessa caverna em busca do novo, em busca do conhecimento, ou seja, é a saída da zona de conforto; o último elemento que a narrativa traz é a luz solar que, no início, causa um desconforto nos prisioneiros, mas que, para Platão, trata-se de uma metáfora para definir a sabedoria. Pode até ser desconfortável e incômodo no início, e até dói, dependendo da ação, mas dói porque agora tomamos conhecimento, e isso ninguém nos tira. É revolucionário.

Sair da sala de ensaio e dos palcos para ir para o mundo da internet apresentar trabalhos para um espectador que pode estar assistindo do outro lado do hemisfério, para alguns artistas, pode ser ágio, mas, para outros, pode ser um processo mais desconfortável, porém, embasado no mito da caverna, tomar conhecimento de um campo novo e apropriar-se dele é mesmo revolucionário.

Há um certo tempo, produzir material para a internet vem sendo uma atividade cultivada e cultuada por muitos artistas e não-artistas (a expressão "não-artista", aqui, é colocada como pessoas que não se declaram fazedores de arte). A produção de conteúdo nesse campo cibernético, antes da pandemia, era uma possibilidade; com o isolamento social decretado, a produção de todas as linguagens artísticas teve que se submeter a idealizar, divulgar, organizar e executar ações virtualmente por meio de salas de videoconferência, sites e aplicativos de celular.

O fato não inédito de trabalhar a tecnologia de multimídia das/nas criações artísticas é um fenômeno praticado e analisado por seus fazedores há um certo tempo. Para a pesquisadora Ana Bernstein:

A crescente incorporação de novas mídias e tecnologias ao teatro e à performance a partir dos anos 1990 resultou em diferentes formas e práticas artísticas, como teatro multimídia, teatro virtual, teatro intermídia, teatro ciborgue, performance digital etc. No campo teórico-crítico, pode-se medir o impacto dessa transformação da cena e das 
artes pela publicação, nos últimos quinze anos, de um número significativo de obras voltadas ao assunto, como é o caso de Multimedia - Video, Installation, Performance (2007) de Nick Kaye, Virtual Theatres (2004) de Gabriella Giannachi, Digital Performance (2007) de Steve Dixon, Cyborg Theatre (2011) de Jennifer Parker-Starbuck e Mapping Intermediality in Performance (2010), editado por Sarah Bay-Cheng et al, para citar apenas algumas no âmbito da língua inglesa. (BERNSTEIN, 2017, p. 402).

A relação teatro e tecnologia é uma falsa dicotomia. Ambos estão em diálogo desde um certo tempo. Compreender o fazer teatral como atividade pensante e geradora de conhecimento pode ser um caminho que leve a pensar sobre as problematizações propostas neste trabalho. Mapear e desenvolver uma atenção especial a um processo de criação cênica possibilita refletir sobre os objetos de cena, composição, teatralidade, fenômeno teatral, dentre muitas outras coisas. Fazer teatro é pensar teatro. André Carreira reflete sobre essa questão:

\begin{abstract}
É importante entender como os processos de criação estabelecem relações entre as práticas criativas e as teorias; tais como o fazer e o pensar podem estar imbricados como parte de um todo que chamamos de fazer artístico. Porque fazer teatro é pensar teatro. (CARREIRA, 2012, p. 2).
\end{abstract}

Partindo dessa compreensão, se deu a ida a campo, que devido as circunstâncias foi dentro da própria casa, a criação dentro de casa torna-se o cerne da metodologia adotada nesta investigação. Criar, escrever, pensar, maturar, experimentar, decidir e outras ações mais que envolvem a criação do produto cênico "El niño" circundam o cotidiano do ator na última semana de maio de 2020 .

\section{1 "El niño": em meio a uma tempestade de ideias}

"El niño" é o nome de um trabalho solo de William Axel, fragmento cênico que faz parte do projeto de pesquisa "Cartografias Homoafetivas", do programa de pós-graduação em Artes, do IFCE - PPG Artes.
A performance traz uma reflexão sobre as violências que se vive no dia a dia; em específico, a homofobia.

A performance tem inspiração em O Pequeno Príncipe, do francês Antoine de Saint-Exupéry, e reúne, em sua dramaturgia, narrativas reais de garotos que sofreram violência física, psicológica e/ou social pelo seu modo de viver e de se relacionar em sociedade. Em cena, tem-se um corpo poético/políti$\mathrm{co}$, considerando o atravessamento com as questões socioculturais que circundam o sujeito criador.

Anne Bogarttem umafala que merece importância e nos ajuda a pensar sobre as decisões compositivas:

Dentro de toda boa peça mora uma questão. Uma peça importante é aquela que levanta grandes questões que perduram no tempo. Montamos uma peça para lembrar de questões relevantes. Lembramos delas em nossos corpos, e as percepções ocorrem em tempo e espaço real. (BOGART, 2011, p. 29).

Eu diria apenas que, em toda obra, mora uma questão. Algo motiva tanto os atores quanto a direção, e isso os leva até a cena. Essa reverberação permeia a obra e chega até o público no momento da apresentação. O artista-criador debruça-se sobre a pesquisa. Campo, mesmo em casa. Sala de estudo, mesmo em casa. Sala de ensaio em casa. Campo. Campo. Campo. O campo é a casa. Um trabalho braçal, artesanal... É preciso transcender!

Dramaturgia construída junto com a composição cênica. Música. Relato. Vivências. Tudo compõe a dramaturgia. O modo como "El niño" estruturou-se faz pensar sobre como a teatralidade ganha novas descobertas a cada processo e a cada dispositivo gerado para composição cênica.

O trabalho tem como matriz de composição a compreensão de uma cena física e ritualística em um estado de "fronteira flutuante", um lugar de transitoriedade, onde o espaço (corpo e lugar) está para a hibridização de manifestações artísticas que possam dialogar no trabalho, num processo transversal entre teatro, dança, literatura, audiovisual e paisagem sonora e visual. Procedimento criativo contemporâneo. O corpo é dramaturgia; o vídeo 
é dramaturgia; o texto é dramaturgia; a paisagem sonora e visual são dramaturgias; o figurino, o cenário e todas as partículas que compõem a cena/vídeo são compreendidas como dramaturgia.

As cenas foram gravadas pelo celular do artista-criador. Trata-se de um aparelho Redmi note 8 que, para o período em que estamos materializando esta pesquisa, é um celular com tecnologia suficiente para uma produção audiovisual consistente. Apontar essa informação é necessário, visto que nos dias de hoje, a cada dia, é lançado um aparelho com tecnologias mais aguçadas, o que desperta possibilidades criativas para o universo virtual.

$O$ vídeo performance tem duração de dez minutos e vinte e três segundos (ME NINO, 2020), (encontra-se disponível na plataforma YouTube; o site no qual está armazenado segue anexo).

Existe uma escolha por repetição de imagens: é como uma necessidade de reforça-las. O exercício é trazer memórias pessoais e expressar por meio de imagens. Em alguns momentos, o desejo era de mostrar para o espectador o que os olhos viam naquele instante que foi dedicado à criação. $O$ que vejo neste momento? É isso que será mostrado.

A ida ao supermercado, a clausura do quarto, a ação de tirar a barba. Isto surgiu a partir de uma técnica de Constantin Stanislavski, na qual o objetivo é transformar uma atividade do cotidiano em ação física.

Tudo é filmado, depois revisitado e, assim, a brincadeira de mapear as imagens de diversas formas transforma-se em um exercício dramatúrgico do trabalho: processo que muitas vezes é feito em sala de ensaio, ou seja, a brincadeira de mapear cenas para construir a dramaturgia, o argumento.

A escolha do nome "El niño", cuja tradução para a língua portuguesa é "O menino", surgiu de um sonho. Nos dias em que o processo de criação estava em curso, o experimento chamava-se "O Pequeno", referência à obra de Antoine de Saint-Exupéry, que é combustível para a criação e alimento dramatúrgico do trabalho.

Mas o título ainda não era agradável, afinal, não se trata de uma adaptação da obra de Saint-
Exupéry. Do tempo/espaço onírico do artista-criador, surgiu esse nome, "El niño". No vídeo performance, essa figura/rapaz, que não verbaliza texto falado, existe uma narração em língua portuguesa, não se apresenta como um brasileiro. São as características físicas dessa persona que revelam nela a expressão de um rapaz latino americano.

\subsection{Dispositivos para "El niño"}

A noção de "dispositivo" é bastante popular no cotidiano. Atualmente, é um termo bastante ligado à área da informática para fazer referência aos outros sistemas associados ao funcionamento dos computadores, por exemplo. Neste sentido, um dispositivo de armazenamento de dados é um componente que permite ler ou escrever informação digital em um meio ou suporte.

Tratando-se do objeto-cena em período de isolamento social, que dispositivos solicitar para uma composição? Quais chaves possibilitam abrir horizontes? Um artista de teatro decide ir a trabaIho em um período de uma semana, mas partindo de que lugar? Em um processo de criação, quais dispositivos possibilitam gerar um material cênico?

Agamben, em seu texto O que é dispositivo?, traz uma hipótese sobre essa terminologia, citando três breves resumos do que Foucault organiza como conceito, a partir do registro de uma entrevista datada de 1977. Embora o próprio Foucault nunca tenha dado uma verdadeira e própria definição a dispositivo, Agamben inicia transcrevendo os conceitos dados pelo filósofo francês:

1) É um conjunto heterogêneo, que inclui virtualmente qualquer coisa, linguístico e não linguístico no mesmo título: discursos, instituições, edifícios, leis, medidas de segurança, proposições, filosóficas etc. a dispositivo em si mesmo e a rede que se estabelece entre esses elementos. 2) o dispositivo tem sempre uma função estratégica concreta e se inscreve sempre em uma relação de poder. 3) É algo de geral (um reseau, uma "rede") porque inclui em si a episteme, que para Foucault e aquilo que em uma certa sociedade permite distinguir o que é aceito como um enunciado científico daquilo que não e científico. (AGAMBEN, 2005, p. 9-10). 
O autor apresenta os conceitos de Foucault dentro do contexto dado e vivido pelo filósofo e seu modo de explicar essa terminologia. Agamben, na sua escrita/pensamento, aborda esse conceito de maneira mais clara dentro de um cotidiano próximo. Ele explica:

Generalizando posteriormente a já amplíssima classe dos dispositivos foucaultianos, chamarei literalmente de dispositivo qualquer coisa que tenha de algum modo a capacidade de capturar, orientar, determinar, interceptar, modelar, controlar e assegurar os gestos, as condutas, as opiniões e os discursos dos seres viventes. Não somente, portanto, as prisões, os manicômios, o panóptico, as escolas, as confissões, as fábricas, as disciplinas, as medidas jurídicas etc, cuja conexão com o poder e em um certo sentido evidente, mas também a caneta, a escritura, a literatura, a filosofia, a agricultura, o cigarro, a navegação, os computadores, os telefones celulares e - porque não - a linguagem mesma, que e talvez o mais antigo dos dispositivos, em que há milhares e milhares de anos um primata - provavelmente sem dar-se conta das consequências que se seguiriam - teve a inconsciência de se deixar capturar. (AGAMBEN, 2005, p. 13).

O artista, enquanto agente-criador do espetáculo e sujeito desafiado a encontrar dispositivos que o levem à composição cênica ou mesmo à uma verdade cênica, cria dispositivos ou faz/busca caminhos que o levem à descoberta desses dispositivos, sendo isto, o próprio ato de gerar/criar dispositivos. Essa é uma questão que está ligada ao desejo do artista-criador de chegar em seu objetivo em cena/vídeo.

Dispositivo vem como algo que opera, impulsiona. Pode-se visualizar a imagem de uma alavanca que possibilita gerar, multiplicar força. Impulsionar à força. Dispositivo, para Foucault, refere-se, explicitamente, a elementos tais como discursos, organizações arquitetônicas, leis, medidas administrativas, enunciados científicos. Podemos entender, assim, que as práticas discursivas e não discursivas contribuem para a construção do dispositivo. (MARCELLO, 2004, p. 2).

Deste modo, dispositivos para a cena é um plural, são discursos, organizações arquitetônicas, são práticas, ferramentas, experimentos, treinamentos, ações dentre outras possibilidades mais.

\section{Algumas considerações}

A percepção de artista-criador que se pode concluir desta experiência é a extração de possibilidades para uma criação artística que, em meio a um isolamento social, pode parecer complexo, no entanto, revela meios para a composição de uma obra.

As reflexões geradas até esse momento deixam pistas de como a construção de "El niño" se manifesta e como deixa possibilidades de caminhos em nossas construções de trabalho em um período de isolamento social.

Os dispositivos produzidos para as composições são diversos. Os dispositivos são muito particulares para cada processo e, inclusive, para cada cena. Cada demanda criativa exige seus dispositivos a partir de suas peculiaridades. Em alguns momentos, a composição vídeo/cênica é impulsionada por meio de uma música ouvida, de um curto-circuito criativo, de uma imagem, de uma leitura e até mesmo da própria obra de inspiração. Algumas cenas/imagens surgem a partir de uma conversa por whatsapp com um amigo ou outro e mostra algo cênico/visual a se experimentar.

Que prazer poder ter essa vivência!

\section{Referências}

AGAMBEN, Giorgio. O que é um dispositivo? Ilha de Santa Catarina $-2^{\circ}$ semestre de 2005.

Bernstein, A. Performance, tecnologia e presença: The Builders Association. Sala Preta, 17(1), 409-428. https://doi.org/10.11606/issn.2238-3867. v17i1p400-419

BOGART, Anne. A preparação do diretor. Trad. Ana Viana. São Paulo. WMF

Martins Fontes, 2011.

CARREIRA, André. Fazer teatro é pensar teatro. Conceição. v. 1, n. 1, 2012. 
MARCELLO, Fabiana de Amorim. O Conceito de Dispositivo em Foucault: mídia e produção agonística de sujeitos-maternos. Educação e realidade, v. 29, n. 1, jan 2004, p. 199-213.

ME NINO, UMA CARTOGRAFIA DE QUARENTENA. William Axel (intérprete). Parte do projeto de pesquisa cartografias homoafetivas do programa de pós-graduação em Artes do IFCE - PPG Artes, 2020. Disponível em: https://www.youtube.com/ watch? $v=i 34$ sam29E-o\& $t=12 s$.

PLATÃO. A república. Trad. Maria Helena da Rocha Pereira. 2 ed. Lisboa: Caloustre Gulbenkian, 1993.

Recebido: 13/09/2020

Aceito: $15 / 02 / 2021$ Aprovado para publicação: 01/04/2021

Este é um artigo de acesso aberto distribuído sob os termos de uma Licença Creative Commons Atribuição 4.0 Internacional. Disponível em: <http://creativecommons.org/licenses/by/4.0>.

This is an open-access article distributed under the terms of the Creative Commons Attribution License 4.0 International. Available at: <http://creativecommons.org/licenses/by/4.0>.

Ce texte en libre accès est placé sous licence Creative Commons Attribution 4.0 International. Disponible sur: <http://creativecommons.org/licenses/by/4.0>. 